\title{
IMPLEMENTASI PENGESAHAN LEMBAGA PENYELESAIAN SANGKETA KONSUMEN (BPSK) OLEH PEMERINTAH REPUBLIK INDONESIA DALAM KONTEKS PERLINDUNGAN KONSUMEN
}

\author{
Abus Samah \\ Universitas Islam Negeri Sultan Syarif kasim Riau \\ Abusamah@uin-suska.ac.id.
}

\begin{abstract}
The implementation of the ratification of the Consumer Dispute Settlement Agency (BPSK) in the Consumer Protection Act creates confusion, especially for the parties involved in resolving consumer disputes. Is it resolved through the Consumer Dispute Settlement Agency or through the Court. In Civil Law Article 49 (1) of the Consumer Protection Law and Article 2 of the Minister of Trade No. 350/MPP/Kep/12/2001 it is stated that the Consumer Dispute Settlement Agency is an institution for resolving consumer disputes outside the General Court. 8 of 1999 concerning Consumer Protection, still provides a liaison with the Consumer Investigation Board, which has been established by the government, which is in charge of handling and resolving consumer complaints but not a court institution. In the context of the Consumer Protection Law, the decision of the Consumer Sangketa Settlement Agency (BPSK) will have the power of execution after every decision made by BPSK must go through a ruling set by the District court.
\end{abstract}

Keywords: Consumer Dispute Settlement Agency, Consumer Protection

\begin{abstract}
Abstrak
Implementasi pengesahan Badan Penyelesaian Sengketa Konsumen (BPSK) dalam Undang-undang Perlindungan Konsumen menimbulkan kebingunan terutama pihak-pihak yang terlibat dalam penyelesaian sangketa konsumen. Apakah diselesaikan melalui Badan Penyelesaian Sangketa Konsumen atau melalui Pengadilan. Dalam Hukum Perdata Pasal 49 (1) UU Perlindungan Konsumen dan Pasal 2 Kepmendag No.350/MPP/Kep/12/2001 disebutkan Badan Penyelesaian Sangketa Konsumen merupakan lembaga penyelesaian sangketa konsumen di luar Pengadilan umum, namun kenyataannya dalam pasal lain dalam UU No. 8 tahun 1999 Tentang Perlindungan Konsumen tetap memberikan penghubung dengan Badan Penyelesaian Sangketa Konsumen yang telah dibentuk oleh pemerintah, yang bertugas menangani dan menyelesaikan sangketa konsumen tetapi bukan lembaga pengadilan. Dalam konteks Undang-undang Perlindungan Konsumen bahwa keputusan Badan Penyelesaian Sangketa Konsumen (BPSK) akan
\end{abstract}


mempunyai kekuatan eksekusi setelah setiap putusan yang dibuat oleh BPSK harus memalui penetapan yang ditetapkan oleh pengadilan Negeri.

Kata Kunci: Lembaga Badan Penyelesaian Sangketa Konsumen, Perlindungan Konsumen

\section{Pendahuluan}

Pada masa sekarang yang serba modern, ${ }^{1}$ kemajuan dibidang industri barang dan jasa telah membawa dampak positif seperti tersedianya produk barang dan jasa. Dalam memproduk suatu barang untuk konsumen tentu pengusaha mencari keuntunganyang sebesarbesarnya sesuai dengan prinsip ekonomi. Dalam upaya mencari keuntungan yang sebesar-besarnya itu para pelaku usaha maka sering terjadi persaingan antara pelaku usaha dengan prilaku masing-masing pengusaha kadang kala dapat merugikan pihak masyarakat konsumen. Dengan ketatnya persaingan antara pengusaha tersebut menimbulkan persaingan $^{2}$ yang tidak sehat ${ }^{3}$ karena pelaku usaha memiliki kepentingan yang saling berbenturan, yang pada gilirannya dapat merugikan pihak konsumen atau masyarakat konsumen. ${ }^{4}$

Faktor lain yang dapat menimbulkan persaingan yang tidak sehat menurut Janus Sina Batok seperti pengaruh konglomerasi, kartel/trust,

${ }^{1}$ Era modern yang juga ditandai dengan kemajuan perkembangan teknologi informatika yang sangat pesat yang pada gilirannya menimbulkan gaya hidup baru dalam system perdagangan. Terjadinya perubahan tersebut diduga dipengaruhi oleh salah satunya dengan kemajuan dibidang teknologi yang berbasis internet.

${ }_{2}$ Persaingan selalu diartikan sebagai tindakan individual yang mementingkan diri sendiri. Dengan me mentingkan diri sendiri, seseorang yang akan bersaing dapat menghalalkan segala cara untuk meemuaskan dirinya. Cara yang ditempuh selalu cendrung melakukan tindakan yang mematikan pesaingnya dengan tindakan yang tidak baik seperti menipu konsumen, mematikan pengusaha. Lihjat: Ayudha D. Prayoga, et.al, Persaingan Usaha dan Hukum yang Mengaturnya di Indonesia, (Jakarta: Proyek ELIPS), 2000, hlm. 1

${ }^{3}$ Persaingan tidak sehat dapat dipahami sebagai kondisi persaingan diantara pelaku usaha yang berjalan secara fair. Sebagaimana telah ddijelaskan dalam Pasal 1 angka 6 UU No. 5 Tahun 1999, Persaingan tidak sehat adalah persaingan antar pelaku usaha dalam menjalankan kegiatan produksi dan atau pemasaran barang dan atau jasa yang dilakukan dengan cara tidak jujur atau melawan hukum atau menghambat persaingan usaha.

${ }_{4}^{4}$ Janus Sinabatok, Hukum Perlindungan Konsumen di Indonesia, Cet.3. Citra Aditya Bakti, Bandung 2019, hlm, 2. 
insider trading, dan persaingan tidak sehat/curang. Adanya gejala konglomerasi, kartel, dan insider trading merupakan konsekuensi ketatnya persaingan usaha. Terjadinya persaingan usaha yang ketat akan dapat menimbulkan praktek-praktek curang dalam menjalankan usaha dalam upaya memenangkan persaingan antar pengusaha. Praktek semacam monopoli, baik legal maupun illegal pada akhirnya cendrung merugikan pihak masyarakat konsumen. Ketika itu menurut Tami Rusli bahwa kedudukan pelaku usaha dan konsumen tidak seimbang, konsumen dapat menjadi objek aktivitas bisnis dari pelaku usaha melalui produk yang dihasilkan tidak memenuhi syarat seperti syarat kesehatan dan keamanan konsumen $^{6}$ Hal ini terjadi disebabkan oleh kurangnya pendidikan konsumen dan rendahnya akan hak-hak dan kewajibannya. ${ }^{7}$ Faktor ini menurut Ari Purwadi juga menjadi penyebab terjadinya perselisihan atau sangketa antara pelaku usaha dengan konsumen. ${ }^{8}$

Agar tidak terjadi hal tersebut perlu adanya regulasi hukum bagi pemerintah dan rakyat konsumen untuk melakukan upaya hukum serta pemberdayaan konsumen dengan melakukan pembinaan dan pendidikan. Landasan hukum ini bertujuan unuk menciptakan iklim usaha yang sehat melalui penyediaan barang dan atau jasa dengan kualitas yang baik. Undang-undang tersebut adalah Undang-undang No. 8 Tahun 1999 Tentang Perlindungan Konsumen.

Adapun yang menjadi pertimbangan disahkan dan berlakunya Undang-undang no. 8 tahun 1999 Tentang Perlindungan Konsumen oleh pemerintah, menurut Gunawan Wijaya antara lain karena ketentuan hukum yang melindungi kepenttingan konsumen di Indonesia belum memadai. Selain itu dalam era global, pembangunanperekonomian

${ }^{5}$ Ibid

${ }^{6}$ Adanya suatu perdagangan baik itu barang maupun jasa yang dilakukan oleh pelaku usaha yang sering kali menyebabkan konsumen dirugikan.

7 Tami Rusli. Penyelesaian Sangketa Konsumen dan Pelaku Usaha Menurut Peraturan Perundang-undangan dalam Jurnal KEADILAN PROGRESIF Volume 3 Nomor 1 Maret 2012.

${ }_{8}^{8}$ Ari Purwadi, Telaah Singkat Tentang Undang-undang Perlindungan Konsumen, Jurnal Hukum dan Keadilan Fakultas Hukum Universitas Indonesia, Vol. 3.2000,hal.117. 
nasional harus dapat mendukung tumbuhnya dunia usaha sehingga mampu menghasilkan beraneka barang dan/atau jasa yang dapat meningkatkan kesejahteraan masyarakat pengusaha dan konsumen. ${ }^{9}$

Berdasar Pasal 1 angka 1 dari Undang-undang tersebut dinyatakan bahwa perlindungan konsumen adalah segala upaya yang menjamin adanya kepastian hukum untuk memberikan perlindungan kepada masyarakat selaku konsumen. ${ }^{10}$ Undang-undang No. 8 tahun 1999 Tentang Perlindungan Konsumen (UUPK) adalah payung hukum untuk perlindungan konsumen, menjadi kriteria untuk mengukur dugaan adanya terjadi pelanggaran hak-hak konsumen, yang pada awalnya diharapkan semua pihak mampu memberikan solusi untuk menyelesaikan perkaraperkara yang terjadi sebagai pelaksanaan dari Undang-undang No. 8 tahun 1999 Tentang Perlindungan Konsumen. Akan tetapi dalam implementasinya telah terjadi permasalahan yang menimbulkan kebingunan pada pihak-pihak yang terlibat dalam proses implementasinya, dalam halnya masuknya peran pengadilan dalam pemeriksaan perkara keberatan terhadap keputusan yang dibuat oleh lembaga BPSK. Permasalahan yang timbul berkaitan dengan aspek Hukum Acara Perdata.

Berdasarkan pasal 1 butir ke 11 Undang-undang No. 8 Tahun 1999 tentang Perlindungan Konsumen dikatakan bahwa Badan Penyelesaian Sangketa Konsumen (BPSK) adalah badan yang bertugas menangani dan menyelesaikan sengketa antara pelaku usaha dan konsumen. Keberadaan BPSK dapat menjadi bagian dari pemerataan keadilan bagi konsumen yang dirugikan oleh pelaku usaha.

Menurut Abdul Halim bahwa lembaga BPSK disahkan oleh pemerintah dengan tugas dan wewenang antara lain meliputi pelaksanaan penanganan dan penyelesaian sengketa konsumen dengan cara melalui

${ }^{9}$ Gunawan Wijaya dan Ahmad Yani, Hukum Tentang Perlindungan Konsumen. Cet. 3. Penerbit PT Gramedia Pustaka Utama, Jakarta, 2019, hlm. 98

${ }^{10}$ Lihat pasal 1 angka 1 Undang-undang No. 8 tahun 1999 Tentang Perlindungan Konsumen. 
mediasi, arbitrase atau konsiliasi, yang selain sebagai media penyelesaian sangketa juga dpat menjatuhkan sanksi administrasi bagi pelaku usaha. ${ }^{11}$

Pada dasarnya UU No. 8 tahun 1999 Tentang Perlindungan telah memberikan perlindungan secara hukum terhadap masyarakat konsumen dan masyarakat pengusaha, namun perlu senantiasa disosialisasikan untuk menciptakan hubungan yang setara dan berkeadilan serta untuk mengimbangi kegiatan pelaku yang menjalankan prinsip ekonomi. Selain itu juga untuk menangani penyelesaian persengketaan antara konsumen dan pelaku usaha, yang pada umumnya meliputi jumlah nilai yang kecil, tetapi dalam prakteknya tidak ada batasan nilai pengajuan gugatan sehingga dimungkinkan gugatan konsumen melebihi nilai yang kecil sebagaimana yang dimaksudkan dalam UU No. 8 Tahun 1999 tentang Perlindungan Konsumen.

Adapun permasalahan yang akan dibahas berkaitan dengan implementasi pengesahan lembaga Badan Penyelesaian Sengketa Konsumen oleh pemerintah dalam kontek Undang-undang perlindungan konsumen dalam upaya penyelesaian sengketa konsumen dan pelaku usaha.

\section{Pembahasan}

1. Dasar Hukum Pengesahan Badan Penyelesaiaan Sengketa Konsumen oleh Pemerintah Republik Indonesia.

a. Dasar Hukum BPSK oleh Pemerintah

Adapun sebagai dasar hukum pengesahan BPSK oleh pemerintah RI adalah Pasal 19 ayat 1 UU No. 8 tahun 1999 Tentang Perlindungan Konsumen dan Keputusan Memperindag No. 350/MPP/Kep/12/2001 tentang Pelaksanaan Tugas dan Wewenang Badan Penyelesaian Sengketa Konsumen.

${ }^{11}$ Abdul Halim Barkatullah, Urgensi Perlindungan Konsumen Dalam Transaksi di E Commerce, Jurnal Hukum, Fakultas Hukum Universitas Islam Indonesia No. 2 Vol.4 April. 2007, hal. 260 
Berdasarkan dasar hukum tersebut telah diatur tentang pembentukan BPSK dengan anggaran BPSK dibebankan pada Anggaran Pendapatan Belanja Negara dan anggaran unuk didaerah dibebankan kepada anggara belanja daerah.

Selanjutnya dalam perkembangannya pada tahun 2001 pemerintah $\mathrm{Rl}$ telah meresmikan BPSK ditandai dengan dikeluarkannya Kepres No. 90 Tahun 2001 tentang Pembentukan BPSK pada Pemerintahan Kota Medan, Kota Palembang, Kota Jakarta Pusat, Kota Jakarta Barat, Kota Bandung, Kota Semarang, Kota Yogyakarta, Kota Surabaya, Kota Malang dan Kota Makasar. Kemudian berdasarkan Kepres No.108 Tahun 2004 dibentuk pula BPSK di Kota Kupang, Kota Samarindah, Kota Suka Bumi, Kota Bogor, Kota Kediri, Kota Mataram, Kota Palangka Raya, dan Kabupaten Kupang, Belitung, Suka Bumi, Bulungan Serang, Ogan Komering Ulu Jene Ponto. Berdasarkan Kepres No. 18 Tahun 2005, pada tanggal 12 Juli Tahun 2005 dibentuk pula Lembaga Penyelesaian Sengketa Konsumen di Kota Padang, Kabupaten Indramayu, Kabupaten Bandung dan Kabupaten Tanggerang.

b. Tujuan Pengesahan BPSK di Daerah oleh Pemerintah

Tujuan pengesahan BPSK oleh pemerintah didaerah pada dasarnya bertujuan untuk menyelesaikan persengketaan konsumen dan pengusaha dapat dilakukan secara cepat, mudah dan lagi murah dibandingkan dengan penyelesaian sengketa di pengadilan. Cepatnya penyelesaian melalui Badan Penyelesaian Sengketa Konsumen karena harus selesai dalam jangka waktu 21 hari kerja, dan tidak dimungkin banding yang dapat memperlama proses penyelesaian sengketa, sebagaimana diatur dalam Pasal 54 ayat (3) dan Pasal 55 UUPK dengan konsep dasar putusan BPSK bersifa final dan mengikat. 
Proses yang mudah melalui Badan Penyelesaiaan sengketa Konsumen karena prosedur administrasi dan proses pengambilan keputusan yang sederhana dan dapat dilakukan sendiri oleh para pihak tanpa diperlukan kuasa hukum. Murah karena biaya persidangan yang dibebankan ringan dapat dijangkau oleh konsumen yang sedang bersengketa. ${ }^{12}$

Ketika konsumen yaitu masyarakat konsumen yang bersengketa dapat menerima keputusan yang telah diputuskan oleh lembaga BPSK, maka keputusan tersebut bersifat final dan mengikat kedua bela pihak yang bersengketa. Oleh karena itu pihak yang menerima keputusan BPSK tersebut tidak perlu lagi ke pengadilan untuk diminta diadili. Jadi dengan disahkan BPSK oleh pemerintah akan dapat mengurangi beban tumpukan perkara di pengadilan.

c. Kelembagaan BPSK

Kelembagaan BPSK yang telah dibentuk oleh pemerintah berdasarkan Pasal 50 Undang-undang Pokok Konsumen terdii dari: (1) Ketua merangkap anggota; (2) Wakil Ketua merangkap anggota; dan (3) Anggota.

Sekretaris dalam lembaga BPSK terdiri dari kepala sekretrais dan anggota, yang pengangkatannya dan pemberhentiannya dilakukan oleh Menperindag. Hal ini telah diatur oleh pemrintah melalui Pasal 51 ayat (1) dan (2) UUPK. Kemudian juga diatur lebih lanjut Kepmenperindag No. 301/MPP/Kep/10/2001 tentang pengangkatan. Pemberhentian anggota dan sekretaris BPSK. Pasal 54 aya (2) UUPK, menyatakan bahwa setia penyelesaian sengketa konsumen dilakukan oleh majelis yang dibentuk oleh ketua BPSK dan dibantu oleh Panitera, sedangkan susunan majelis siding harus ganjil, dengan ketentuan minimal 3 orang yang mewakili semua unsur, yaitu unsur

${ }^{12}$ Yusuf Shofie, Penyelesaian Sengketa Konsumen Menurut Undang-undang Perlindungan Konsumen. Teori dan Praktek Penegakan Hukum, Cet.4 Citra Aditya, Tahun 2019, hlm. 17 
pemerintah, konsumen, dan pelaku usaha. Pasal 18 SK Memperindag No. 350/MPP/Kep/12/2001, menyatakan Ketua Majelis BPSK harus dari unsur Pemerintah, walaupun tidak berpendidikan hukum.

\section{d. Penyelesaian sengketa oleh BPSK}

Penyelesaian sengketa yang dilakukan oleh BPSK dilakukan dengan cara konsialisasi atau mediasi, ${ }^{13}$ tanpa melalui pengadilan. ${ }^{14}$ yang berwenang menetapkan siapa yang menjadi personilnya baik sebagai ketua majelis yang berasal dari unsur Pemerintah maupun anggota majelis yang berasal dari unsur konsumen dan pelaku usaha adalah ketua dari lembaga Badan Penyelesaian Sengketa Konsumen.

Kalau penyelesaian sengketa secara arbitrase, maka yang berwenang menentukan siapa yang menjadi majelis hakim adalah para pihak yang sedang bersengketa. Makanya para pihak dapat memilih arbiter yang mewakili kepentingan, yang salah satunya dari lembag Badan Penyelesaian sengketa konsumen sebagai arbiter yang akan menjadi anggota majelis. dan begitu juga dari pihak pelaku uasaha sebagai arbiter yang menjadi anggota majelis. Setelah itu, setiap arbiter yang telah ditentukan secara bersama antara pihak konsumen dan pihak pengusaha akan memilih pihak ketiga yang berasal dari unsur pemerintah dari anggota BPSK yang akan menjadi ketua Majelis. ${ }^{15}$ Prosedur untuk memilih arbiter hasil pemilihan konsumen dan pelaku usaha, demikian juga arbiter ketika dari unsur pemerintah dilakukan dengan mengisi formulir arbiter, akan ditetapkan

${ }^{13}$ Menurut Mode Udiana bahwa penyelesaian sengketa konsumen dengan cara konsoliasi, mediasi dan arbitrase didasarkan pada oleh pilihan dan persetujuan para pihak berhak memilih melalui proses bagaimana dalam menyelesaikan sengketa atau permasalahannya, sebagaimana diatur dalam Pasal 4 dan Pasal 2 SK Memperindag No. 350/MPP/Kep/12/2001. Lihat: Mode Udiana, Rekontruksi Pengaturan Penyelesaian Sengketa Penanaman Modal Asing, Udayana University Press, Denpasar, 2011.

${ }^{14}$ Erman Raja Gukguk, Budaya Hukum dan Penyelesaian Sengketa Perdata di Luar Pengadilan, Jurnal Magister Hukum, UII, Yogyakarta, Volume II No. 4 Oktober, 2000, hlm. 7

${ }^{15}$ Susanti Adi Nugraha, Proses Penyelesaian Sengketa Konsumen Ditinjau dari Hukum Acara Perdata Serta Ke Pola Implementasinya Cet,2, Jakarta, Penerbit Kencana Pernada Media Group Tahun 2018, hlm. 74 
oleh Badan Penyelesaian Sengketa Konsumen sebagai majelis yang menangani sengketa konsumen dengan cara arbitrase melalui penetapan.

\section{e. Penetapan Panitia BPSK}

Penetapan panitia Badan Penyelesaian Sengketa Konsumen berasal dari anggota secretariat yang ditetapkan oleh ketua BPSK dengan tugas diantaranya: (1) mencatat jalannya proses penyelesaian sengketa konsumen; (2) menyimpan berkas perkara; (3) menjaga barang bukti; (4) membantu majelis menyusun putusan; (5) membantu penyampaian putusan kepada konsumen dan pelaku usaha; (6) membuat berita acara persidangan; (7) membantu majelis dalam tugas-tugas penyelesaian sengketa.

Berdasarkan Pasal 56 ayat 1 dan 2 SK Memperindag No. 350/MPP/Kep/12/2001, disebutkan bahwa Ketua majelis atau anggota panitera Badan Penyelesaian Sengketa Konsumen berkewajiban untuk mengundurkan diri apabila terdapat permintaan ataupun tanpa permintaan jika terikat hubungan keluarga sedarah atau semenda sampai derajat ketigaa atau hubungan suami istri meskipun telah bercerai dengan pihak yang bersengketa.

Kemudian sebagai gungsi strategi dari BPSK, yaitu : (1) BPSK berfungsi sebagai instrument hukum penyelesaian sangketa konsumen diluar pengadilan, yaitu melalui konsiliasi, mediasi dan arbitrase; (2) Melakukan pengawasan terhadap pencantuman klasula oleh pelaku usaha, termasuk klasula baku yang dikeluarkan oleh PT.PLN (Persero) atau dibidang kelistrikan, PT. Telkom (Persero) dibidang telekomunikasi, bank-bank milik pemerintah maupun swasta, perusahaan pembiayaan dan lain-lain. Salah satu fungsi strategis ini adalah untuk menciptakan keseimbangan kepentingan-kepentingan pelaku usaha dan konsumen. 
2. Pengesahan Badan Penyelesaian Sengketa oleh Pemerintah Sebagai Lembaga Penyelesaian Perkara Kecil dan Sederhan.

Pemerintah melalui pasal 47 Undang-undang perlindungan konsumen dikatan bahwa penyelesaian sangketa konsumen di luar pengadilan di selenggarakan untuk mencapai kesepakatan mengenai bentuk dan besarnya ganti kerugian dan/atau mengenai tindakan tertentu untuk menjamin tidak akan terjadi kembali atau tidak akan terulang kembali kerugian yang diderita oleh konsumen.

Dalam pasal 60 ayat (2) UUPK, menyatakan bahwa sanksi adminitrasi berupa penetapan ganti kerugian paling banyak sebesar Rp.200 juta yang dana dibebankan kepada pelaku usaha, tampak sebenarnya lembaga BPSK yang dibentuk oleh pemerintahhan yaitu untuk penyelesaian sangketa konsumen dengan jumlah nilai yang kecil.

Agar putusan pemerintahan melalui BPSK mempunyai kekuatan eksekusi, putusan tersebut harus dimintakan penetapan eksekusi pada pengadilan negri di tempat tinggal konsumen yang dirugikan.

\section{Kesimpulan}

Berdasarkan pembahasan yang telah dilakukan oleh penulis di atas, maka dapat disimpulkan sebagai berikut:

1. Pengesahan BPSK oleh pemerintah RI berdasarkan pasal 49 ayat 1 Undang-undang No.8 tahun 1999 tentang perlindungan konsumen dan keputusan memperindag No. 350/MPP/Kep/12/2002 yang mengatur bahwa setiap kota atau kabupaten harus dibentuk BPSK.

2. Lembaga Badan Penyelesaian Sangketa Konsumen (BPSK) dibentuk dan disahkan oleh pemerintah adalah untuk menyelesaikan kasuskasus sengketa konsumen yang berukuran kecil dan bersifat sederhana, dan penyelesaian sengketa dapat dilakukan secara cepat ,mudah dan murah serta putusan BPSK bersifat final dan mengikat, jika diterima oleh kedua belah pihak yang bersengketa. 
3. BPSK dibentuk dan disahkan oleh pemerintah dengan biaya pelaksanaan dibebankan pada APBN dan APBD.

4. BPSK dibentuk dan disahkan oleh pemerintah adalah untuk menyelesaikan sengketa konsumen dengan cara konsiliasi atau mediasi dan arbitrase. 


\section{Daftar Pustaka}

Abdul Halim Barkatullah,Urgensi Perlindungan Konsumen Dalam Transaksi di E Commerce, Jurnal Hukum, Fakultas Hukum Universitas Islam Indonesia No.2.Vol.4.April 2007

Ari Purwadi,Telaah Singkat Tentang Undang-undang Perlindungan Konsumen, Jurnal Hukum dan Keadilan Fakultas Hukum Universitas Islam Indonesia,Vol,3.No.3.2000

Ayudha D. Prayoga, et.al, Persaingan Usaha dan Hukum yang Mengaturnya di Indonesia, (Jakarta: Proyek ELIPS), 2000 Az.Nasution, Aspek Hukum Perlindungan Konsumen, Jurnal Teropong, Edisi Mei, 2003, Mayarakat Pemantau Keadilan Indonesia Erman Raja Gukguk, Budaya Hukum dan Penyelesaian Sengketa Perdata di Luar Pengadilan, Jurnal Magister Hukum, UII, Yogyakarta, Volume II No. 4 Oktober, 2000

Gunawan Wijayadan Ahmad Yani, Hukum Tentang Perlindungan Konsumen, cet,3, penerbit PT Gramedia Pustaka Utama, Jakarta, 2019

Janus Sinabatok, Hukum Perlindungan Konsumen di Indonesia, Cet.3..Citra Aditya Bakti, Bandung 2019

Mode Utama, Rekontruksi Pengaturan Penyelesaian Sangketa Penanaman Modal Asin, Udayana University Press, Denpasar,2011

Susanti Adi Nugrohho, Proses penyelesaian sengketa Konsumen ditinjau dari hukum acara perdata serta kendala implementasinya. Cet, 2.Jakarta, Penerbit Kencana Pernada Media Group Tahun 2018

Tami Rusli. Penyelesaian sengketa antara konsumen dan pelaku usaha menurut peraturan perundang-undangan jurnal KEADILAN PROGRESIF Volume 3 Nomor 1 Maret 2012

Yusuf Shofie, Penyelesaian Sengketa Konsumen Menurut Undangundang Perlindungan Konsumen.Teoridan Prektek Penegakan Hukum, Bandung,Cet.4 Citra Aditya Bakti,Tahun 2019 